Moseyko A., Senior Lecturer of the Department of General Legal disciplines, Dnipro Humanitarian University (Dnipro, Ukraine)

\title{
NATIONAL SECURITY OF UKRAINE AS AN OBJECT OF PUBLIC ADMINISTRATION
}

The article is devoted to the study of the features of public administration in the field of national security of Ukraine. The essence of the state is revealed, the main purpose of which should be considered the achievement of general security and wellbeing. The role of the modern state in the context of globalization, which significantly changes its traditional functions and methods of management, is defined. Emphasis is placed on the feasibility of identifying areas of public administration in the field of national security of Ukraine, where each direction provides for possible methods of influence, the object of public administration and a set of relevant measures to counter at the state level. The significance of social relations associated with ensuring national security into separate groups, objects, which would allow analyzing them and exercising state control on the part of society, is characterized. The system of areas of public administration in the field of national security of Ukraine is considered taking into account the degree of their relevance and is formulated as follows: military, environmental, economic, political and informational direction. Attention is focused on the new understanding of the mutual influence and interdependence of the national and international aspects of security, where the national security of an individual state is part of or subsystem of regional security, which, in turn, is international and global security.

Key words: global security, state security, international security, national security, public administration, public administration facility, regional security, public security.

\section{DOI https://doi.org/10.33766/2524-0323.86.52-68 \\ УДК 342.572}

\author{
В. Ф. Нестерович, \\ доктор юридичних наук, доцент \\ завідувач кафедри державно-правових дисциплін \\ Луганського державного університету \\ внутрішніх справ імені Е. О. Дідоренка \\ (м. Сєвєродонецьк, Україна) \\ e-mail: mail@lduvs.edu.ua \\ (iD https://orcid.org/0000-0003-2614-0426
}

\section{ОСОБЛИВОСТІ ПРОВЕДЕННЯ ВИБОРІВ ДО ОРГАНІВ МІСЦЕВОГО САМОВРЯДУВАННЯ В УКРАЇНІ}

У статті розкрито особливості проведення виборів до органів місцевого самоврядування в Україні. Указано, що вибори до органів місцевого самоврядування є найбільш наближеним до громадян видом виборів. Чергові вибори до органів місцевого самоврядування є чи не найбільш складними. При 
проведенні виборів до органів місцевого самоврядування в Україні мають місце вісім основних особливостей, які помітно вирізняють цей вид виборів від парламентських та президентських в Україні.

Ключові слова: вибори, виборче право, виборчий процес, виборча система, органи місцевого самоврядування, Україна.

Постановка проблеми. Вибори до органів місцевого самоврядування $є$ найбільш наближеним до громадян видом виборів. В Україні для регулювання порядку організації та проведення виборів до органів місцевого самоврядування, не враховуючи численні зміни до самих законів, було прийнято шість законів, які скасували дію попередніх: Закон № 3996-XII «Про вибори депутатів і голів сільських, селищних, районних, міських, районних у містах, обласних Рад» від 24 лютого 1994 року, Закон № 14/98-ВР «Про вибори депутатів місцевих рад та сільських, селищних, міських голів» від 14 січня 1998 року, Закон № 1667-IV «Про вибори депутатів Верховної Ради Автономної Республіки Крим, місцевих рад та сільських, селищних, міських голів» від 06 квітня 2004 року; № 2487-VI «Про вибори депутатів Верховної Ради Автономної Республіки Крим, місцевих рад та сільських, селищних, міських голів» від 10 липня 2010 року та Закон № 595-VIII «Про місцеві вибори» від 14 липня 2015 року. На сьогодні порядок проведення місцевих виборів в Україні визначається Конституцією України [1], Кодексом адміністративного судочинства України [2], Законами України № 595-VIII [3] «Про місцеві вибори» від 14 липня 2015 року, № 1932-IV «Про Центральну виборчу комісію» від 30 червня 2004 року [4], № 698-V «Про Державний реєстр виборців» від 22 лютого 2007 року [5], а також деякими постановами Кабінету Міністрів України та Центральної виборчої комісії. Найбільш спірні моменти проведення місцевих виборів знайшли своє розв'язання в низці Рішень Конституційного Суду України. Місцеві вибори одночасно на всій території України було проведено в 1994, 1998, 2002, 2006, 2010 та 2015 роках. У 1995 році відбулися вибори депутатів і голів місцевих Рад народних депутатів в Автономній Республіці Крим, а вже у 2008 році позачергові вибори до Київської міської ради. Вибори до органів місцевого самоврядування суттєво вирізняються порівняно з іншими, які мають місце в Україні. Вибори до органів місцевого самоврядування в Україні мають чи не найбільш складний характер організаційного здійснення порівняно 3 виборчим процесом у президентській та парламентській кампаніях.

Аналіз останніх досліджень і публікацій. Питання проведення виборів до органів місцевого самоврядування в Україні відображено в працях багатьох українських учених, середяких є О. Батанов [6], О. Богашов [7], М. Козюбра [8], Р. Максакова [9], О. Марцеляк [10], В. Погорілко [11], М. Смокович [12], М. Ставнійчук [11], В. Федоренко [13] та ін. Однак попри грунтовні праці вищезазначених дослідників питання особливостей проведення виборів до органів місцевого самоврядування в Україні й досі $€$ не до кінця вивченим.

Формування цілей. Метою цієї статті $є$ розкриття особливостей проведення виборів до органів місцевого самоврядування в Україні.

Виклад основного матеріалу. Аналіз законодавства про місцеві вибори та практики проведення виборів до органів місцевого самоврядування в 
Україні дає змогу стверджувати, що вони суттєво відрізняються від парламентських та президентських Тож виокремимо вісім основних особливостей проведення виборів до органів місцевого самоврядування в Україні.

1. Велика кількість осіб, які обираються на виборах до органіВ місиевого самоврядування. Посадових осіб, яких обирають на виборах до органів місцевого самоврядування, можна умовно розділити на п'ять категорій: 1) депутати обласних та районних рад - органів місцевого самоврядування, які представляють спільні інтереси територіальних громад сіл, селищ та міст (регіональний рівень місцевого самоврядування); 2) депутати міських, районних у містах, сільських та селищних рад - органів місцевого самоврядування територіальних громад (місцевий рівень місцевого самоврядування); 3) міського, селищного та сільського голову - головної посадової особи територіальної громади відповідно села (добровільного об'єднання в одну територіальну громаду жителів кількох сіл), селища, міста; 4) старости - посадової особи місцевого самоврядування, що діє в селах, селищах, визначених за рішенням місцевої ради об'єднаної територіальної громади, утвореної відповідно до Закону України «Про добровільне об'єднання територіальних громад», за винятком ऑї адміністративного центру.

Запровадження посади старости в об'єднаних територіальних громадах стало проблемою в межах проведення в Україні реформи щодо децентралізації влади. На сьогодні староста є єдиною виборною особою, яка не передбачена Конституцією України. Перші вибори старости в Україні відбулися 17 січня 2016 року в селі Ірдинь Черкаської області. Загалом за даними Центральної виборчої комісії протягом 2016 року перші місцеві вибори пройшли в об'єднаних територіальних громадах по всій Україні, на яких було обрано 529 старост. Відповідно до ст. 14-1 Закону України «Про місцеве самоврядування» старосту обирають жителі села, селища (сіл, селищ), розташованого на території відповідного старостинського округу, на основі загального, рівного, прямого виборчого права в спосіб таємного голосування i в порядку, визначеному законом. Староста здійснює свої повноваження на постійній основі. Повноваження його починаються з моменту складення ним присяги відповідно до Закону України «Про службу в органах місцевого самоврядування» на пленарному засіданні відповідної сільської, селищної, міської ради, на якому відповідною територіальною виборчою комісією було оголошено рішення щодо його обрання та реєстрації. Строк повноважень старости, обраного на чергових виборах, становить п'ять років, крім випадків дострокового припинення його повноважень з підстав і в порядку, визначених цим Законом [14].

2. Громова застава на виборах до органів місиевого самоврядування В Україні має обмежении характер та не застосовується стосовно селищних та міських голів, старост, а також депутатів селищних та сільських рад. Грошова застава, згідно зі ст. 44 Закону України «Про місцеві вибори», вноситься місцевою організацією партії, яка висунула виборчий список кандидатів у депутати в багатомандатному виборчому окрузі, кандидата на посаду міського голови, або організацією відповідної партії вищого рівня, а також особою, яка висувається кандидатом на посаду міського голови в спосіб самовисування, 
після початку виборчого процесу та до подання документів територіальній виборчій комісії для реєстрації кандидатів у безготівковому порядку на спеціальний рахунок відповідної територіальної виборчої комісії [2].

Розмір грошової заяви на місцевих виборах в Україні є пропорційним до кількості виборців відповідних області, району, міста, району в місті та визначається таким чином: 1) для кандидата на посаду міського голови - 3 розрахунку чотири розміри місячної мінімальної заробітної плати на кожні 100 тисяч виборців відповідного одномандатного виборчого округу; 2) для виборчого списку кандидатів у депутати Верховної Ради Автономної Республіки Крим, обласної, районної, міської, районної в місті ради, висунутого в багатомандатному виборчому окрузі, - з розрахунку чотири розміри місячної мінімальної заробітної плати на кожні 100 тисяч виборців відповідного багатомандатного виборчого округу. Грошова застава на місцевих виборах повертається відповідному суб'єктові внесення в разі, якщо відмовлено в реєстрації відповідного кандидата, усім кандидатам, включеним до виборчого списку, якщо відповідні вибори були визнані такими, що не відбулися, або якщо за результатами місцевих виборів кандидат визнаний обраним міським головою або місцева організація політичної партії, що висунула список кандидатів у депутати місцевих рад, отримала право на участь у розподілі депутатських мандатів. В інших випадках грошова застава не повертається й перераховується територіальною виборчою комісією відповідно до Державного бюджету України, бюджету АРК, місцевого бюджету [2].

3. Під час виборів до органів місиевого самоврядування застосовується три різні види виборчої системи: 1) мажоритарна виборча система абсолютної більшості при обранні міського голови (міст, кількість виборців у яких дорівнює або є більшою ніж 90 тисяч); 2) мажоритарна виборча система відносної більшості при обранні сільського, селищного, міського голови (міст, кількість виборців у яких є меншою ніж 90 тисяч), старост, а також депутатів сільських та селищних рад; 3) пропорційна виборча система із закріпленням кандидатів за територіальними виборчими округами при обранні депутатів обласних, районних, міських та районних у містах рад.

Проведення виборів міського голови (міст, кількість виборців у яких дорівнює або є більшою ніж 90 тисяч) за мажоритарною системою абсолютної більшості є відносно новим явищем для України та вперше було застосовано на місцевих виборах 2015 року. Повторне голосування на виборах міського голови у 2015 році відбулося у 29-ти з 35-ти міст. Головним лейтмотивом переходу в межах мажоритарної виборчої системи від відносної до абсолютної більшості стало підвищення рівня представництва обраних міських голів у великих містах, оскільки на попередніх місцевих виборах доволі часто траплялися випадки, коли на виборах міських голів перемогу здобували кандидати, які набрали третину, а то й менше голосів виборців. За даними Центральної виборчої комісії в 2010 році на виборах міського голови в м. Житомирі кандидат В. Дебой для перемоги на виборах набрав 19,9 \%, у м. Івано-Франківську кандидат В. Анушкевичус - 27,2 \%, у м. Херсоні кандидат В. Сальдо - 28,61 \%, у м. Харкові кандидат Г. Кернес - 
30,09 \%, у м. Луцьку кандидат М. Романюк - 32,8\%, у м. Ужгороді кандидат В. Погорєлов - $33 \%$ [15].

Водночас варто звернути увагу, що проведення виборів міського голови (міст, кількість виборців у яких дорівнює або є більшою ніж 90 тисяч) за мажоритарною системою абсолютної більшості має складніший характер, через те що в значній частині випадків для остаточного встановлення результатів виборів потрібно проводити повторне голосування. Крім того, застосування додаткових виборчих процедур, як правило, призводить до здорожчання проведення виборів указаних міських голів та збільшує їх здійснення в часі.

Мажоритарна виборча система відносної більшості має більш широке застосування при проведенні виборів до органів місцевого самоврядування в Україні, ніж система абсолютної більшості. На сьогодні мажоритарна виборча система відносної більшості практикується на місцевих виборах при обранні міських (міст, кількість виборців, у яких є меншою ніж 90 тисяч), селищних, сільських голів, старост, а також депутатів селищних та сільських рад. Зазвичай при застосуванні мажоритарної виборчої системи відносної більшості в Україні використовуються одномандатні виборчі округи, хоча у вітчизняній практиці проведення виборів можна також побачити й деяке відхилення від цього правила. Зокрема, характерною особливістю чергових місцевих виборів 1998 та 2002 років стало те, що відповідно до Закону України № 14/98-ВР «Про вибори депутатів місцевих рад та сільських, селищних, міських голів» від 14 січня 1998 року вибори депутатів районної та обласної рад проводилися за мажоритарною виборчою системою відносної більшості по багатомандатних виборчих округах [16].

Перше застосування пропорційної виборчої системи на місцевих виборах в Україні припадає на вибори до органів місцевого самоврядування 2006 року, на яких було використано один з основних їі різновидів - систему жорстких списків. Цей вид виборчої системи практикувався на місцевих виборах 2006 року при обранні депутатів обласних рад, міст Києва та Севастополя, районних, міських і районних у містах рад. Проведення вказаних виборів за пропорційною виборчою системою жорстких списків дає змогу виокремити такі позитивні сторони пї застосування в Україні: 1) сприяння політичному структуруванню українського суспільства; 2) збільшення ролі політичних партій у державному та суспільному житті; 3) орієнтування політичних партій на виборців по всій державі, а не в якомусь певному регіоні чи регіонах; 4) підвищення відповідальності політичних партій перед виборцями.

Утім обрання місцевих рад за пропорційною виборчою системою жорстких списків виявило низку недоліків ії практичного застосування в українських умовах:

1) суттєво було збільшено роль партійного керівництва у формуванні виборчих списків депутатів місцевих рад. Саме від керівників політичних партій та їх близького оточення почало залежати, хто з кандидатів та на якому місці буде у виборчому списку місцевої організації політичної партії для участі в місцевих виборах. Виборцям відводилася лише номінальна та 
формальна роль у висуванні кандидатів у депутати, а під час голосування виборці взагалі не мали жодної можливості вплинути на порядкове розміщення кандидатів у виборчому списку;

2) наявна процедура висування кандидатів у депутати лише через політичні партії значно ускладнила можливість реалізації пасивного виборчого права позапартійними кандидатами на місцевих виборах. Хоч виборче законодавство України й передбачало можливість висування за виборчими списками місцевої організації політичної партії позапартійного кандидата, на практиці здійснення цього права повністю залежало від рішення керівництва політичної партії, яке легітимізувалося на відповідному партійному з'їзді;

3) набула широкого поширення практика «продажу» керівництвом політичних партій місць у так званій «прохідній частині» виборчого списку. Наслідком цьому стало те, що до місцевих рад було обрано багато представників фінансово-промислових груп, які прийшли до колегіальних представницьких органів влади для того, щоб відстоювати та захищати власні бізнес-інтереси, а не представляти інтереси своїх виборців;

4) порушено територіальний розподіл депутатів за виборчими округами. Наприклад, зі 120 депутатів Одеської обласної ради 94 були жителями обласного центру, три - взагалі киянами; а 11 районів із 26-ти й 3 міста обласного значення із 7 не здобули представництва в Одеській обласній раді [17];

5) обрання депутатів у багатомандатному виборчому окрузі за системою жорстких списків призвело до розриву зв'язку між конкретним депутатом та виборцями у виборчому окрузі, а також міжвиборчий період у діяльності місцевих рад. Наслідком цьому стало те, що більшість виборців просто не знали, хто з депутатів представляє їх інтереси та до кого з депутатів місцевої ради можна було звернутися в разі потреби;

7) обрання обласних рад, міст Києва та Севастополя, районних, міських i районних у містах рад за пропорційною виборчою системою жорстких списків призвело до надмірної політизації діяльності місцевих рад та втягнення їх до політичної боротьби на загальнонаціональному рівні. Це виявилося як у внутрішньому протистоянні між різними депутатськими фракціями в середині місцевих рад, аж до блокування їх діяльності, так і в прийнятті деякими місцевими радами рішень, які явно виходили за межі їх компетенції. Наприклад, ухвалення місцевими радами Феодосії, Партеніта, Сімферополя та інших населених пунктів в Автономній Республіці Крим рішень про оголошення міст та селищ «територією вільної від НАТО».

Повернення до пропорційної виборчої системи відбувається при проведенні місцевих виборів 2015 року, коли вибори депутатів обласних, районних, міських та районних у містах рад уперше відбулися в Україні за пропорційною виборчою системою за виборчими списками із закріпленням кандидатів за територіальними виборчими округами, на які поділяється багатомандатний виборчий округ. Головним лейтмотивом їі запровадження стало прагнення щодо збільшення ролі виборців під час голосування у визначенні місця кандидатів у виборчих списках місцевих організацій політичних партій. Для цього кандидати у виборчих списках місцевих 
організацій партій були закріплені за конкретними територіальними виборчими округами, від яких вони й висувалися до відповідної місцевої ради. Територіальна «прив'язка» кандидатів була здійснена для забезпечення територіального представництва депутатів у місцевих радах.

Загалом рух у розвитку пропорційної виборчої системи в Україні до персоніфікованого голосування виборців за кандидатів, які висунуті через виборчі списки місцевих організацій політичних партій, є позитивним моментом. Важливим кроком уперед також стало вирівнювання за гендерною ознакою виборчих списків кандидатів. Зокрема у ч. 3 ст. 4 Закону України «Про місцеві вибори» було встановлено вимогу, що представництво осіб однієї статі у виборчих списках кандидатів у депутати місцевих рад у багатомандатних виборчих округах має становити не менше $30 \%$ загальної кількості кандидатів у виборчому списку [1].

Водночас практичне застосування пропорційної виборчої системи за виборчими списками із закріпленням кандидатів за територіальними виборчими округами при обранні депутатів обласних, районних, міських та районних у містах рад виявило й суттєві недоліки:

1) наявна пропорційна виборча система виявилася досить складною для практичного застосування іï виборчими комісіями та для розуміння виборцями. Це призвело до допущення як з боку членів виборчих комісій, так і виборців великої кількості помилок та порушень під час проведення місцевих виборів, значна частина яких була викликана недостатнім розумінням нових виборчих правил та процедур;

2) механізм реалізації виборцями права висування кандидатів у депутати обласної, районної, міської, зокрема міст Києва та Севастополя, районної в місті ради у відповідних багатомандатних виборчих округах тільки через місцеві організації політичних партій звузило можливість для участі у виборах до вказаних місцевих рад незалежних та позапартійних кандидатів;

3) вимоги до територіальних виборчих округів 3 виборів депутатів обласної ради поставили в невигідне становище великі міста, такі як: Харків, Одеса та Львів,- порівняно з більш дрібними адміністративно-територіальними одиницями в областях, які мали переваги в територіальному представництві через установлений Законом України «Про місцеві вибори» 20\%-вий ліміт кількості депутатів, які представляють міста в обласних радах;

4) перерахунок голосів виборців у відсотки призвів до ситуації, коли кандидати, які мали найбільшу підтримку в певних виборчих округах, не були обрані, тоді як кандидати, які були другими та третіми за результатами виборів, отримали місця в місцевих радах. Це своєю чергою поставило досить гостро питання щодо здатності цієї виборчої системи відображати реальний стан волевиявлення виборців;

5) механізм установлення результатів голосування виборців за новою пропорційною системою виявився таким, що порушує конституційний принцип рівномірного представництва територіальних громад. Унаслідок чого декілька виборчих округів у багатомандатному виборчому окрузі не мали представництва в місцевих радах, тоді як інші округи були представлені 
депутатами в кількості до трьох осіб. Зокрема залишилися без представництва в Чернівецькій області 21 виборчий округ, у Харківській області - 27, у Житомирській області - 21 виборчий округ та у Львівській області - 22 виборчі округи. Крім того, деякі обласні центри, наприклад, Чернігів, узагалі не були представлені у відповідних обласних радах [18].

4. Проведення виборів до органів місиевого самоврядування здійснюється за відповідними територіальними одномандатними та багатомандатними виборчими округами. По єдиних одномандатних виборчих округах обираються міські, селищні та сільські голови, старости, а також депутати селищних та сільських рад. По багатомандатних територіальних виборчих округах обираються депутати обласних, районних, міських та районних у містах рад. Одночасне проведення різних видів виборів до органів місцевого самоврядування створює додаткове навантаження як на місцеві організації політичних партій, які висунули своїх кандидатів для участі в місцевих виборах, так і на територіальні та дільничні виборчі комісії, які в межах своїх повноважень мають забезпечити належне здійснення виборчого процесу на відповідних місцевих виборах.

5. Розгалужена система територіальних виборчих комісій, які мають свій особливий статус, порядок формування, склад та повноваження. Територіальна виборча комісія - це постійно діючий колегіальний орган, до повноваження якого належить організація та проведення місцевих виборів на відповідному територіальному виборчому окрузі та забезпечення на ньому додержання й однакового застосування законодавства України про місцеві вибори. Територіальні виборчі комісії є особливим видом виборчих комісій, оскільки здійснюють свої повноваження лише під час підготовки та проведення місцевих виборів в Україні. Назва «територіальні виборчі комісії» зумовлена передусім тим, що в основу побудови їх системи, закладений територіальний принцип здійснення ними своїх повноважень.

Територіальні виборчі комісії мають деякі сутнісні риси, які визначають їх особливий характер в Україні:

1) є постійно діючими колегіальними органами;

2) функціонують лише при проведенні місцевих виборів;

3) здійснюють свої повноваження в межах території відповідного виборчого округу або виборчого територіального округу в межах адміністративно-територіальної одиниці стосовно відповідних місцевих виборів;

4) до складу територіальної виборчої комісії можуть входити не всі виборці України, а лише ії громадяни, які мають право голосу на цих місцевих виборах;

5) члени територіальної виборчої комісії здійснюють свої повноваження до сформування на чергових місцевих виборах у порядку, передбаченому Законом України «Про місцеві вибори», нового складу відповідної територіальної виборчої комісії;

6) територіальні виборчі комісії мають п'ятирівневу систему: 1) виборча комісія Автономної Республіки Крим та обласні виборчі комісії; 2) районні виборчі комісії; 3) міські виборчі комісії; 4) районні в містах виборчі комісії (у містах з районним поділом); 5) селищні, сільські виборчі комісії; 
7) багаторівневий характер формування: Центральна виборча комісія формує склад обласних, районних (крім районів в АРК), міських (міст обласного значення, міст Києва, Севастополя), районних у містах Києві, Севастополі територіальних виборчих комісій; Верховна Рада Автономної Республіки Крим затверджує склад виборчої комісії АРК; виборча комісія АРК формує склад районних (районів в АРК), міських (міст республіканського в AРК значення) територіальних виборчих комісій; районні територіальні виборчі комісії формують склад міських (крім вищезазначених міст), сільських, селищних територіальних виборчих комісій; міські територіальні виборчі комісії (у містах з районним поділом, крім Києва та Севастополя) формують склад районних у місті територіальних виборчих комісій; міські територіальні виборчі комісії міст, до складу яких входить інше місто, селище, село, формують склад відповідних міських, селищних, сільських територіальних виборчих комісій;

8) наявність внутрішньої підпорядкованості, за якої сільська, селищна, районна в місті, міська, районна територіальна виборча комісія підпорядковується відповідній міській, районній, обласній територіальній виборчій комісії, виборчій комісії АРК, яка встановлює результати місцевих виборів відповідної ради або міського голови.

6. Велика кількість виборчих бюлетенів під час голосування, що уповільнюе роботу дільничних виборчих комісій під час видачі виборчих бюлетенів, здійснення безпосереднього волевиявлення вибориів, підрахунок виборчих бюлетенів та встановлення остаточного результату виборів. Зокрема виборець для голосування може отримати аж шість виборчих бюлетенів для обрання: 1) депутатів обласних рад; 2) депутатів районних рад; 3) депутатів міських, селищних або сільських рад; 4) депутатів районних у містах рад (у містах 3 районним поділом); 5) міських, селищних або сільських голів; 6) старост (в утворених об'єднаних територіальних громадах, де вони діють). Позитивним кроком щодо полегшення організації проведення чергових місцевих виборів в Україні та збільшення уваги виборців до місцевих кандидатів та місцевих організацій політичних партій стало проведення чергових місцевих виборів, починаючи з 2010 року, окремо від парламентських виборів. До цього часу місцеві вибори проводилися одночасно 3 парламентськими виборами, унаслідок чого місцеві вибори були в «тіні» парламентських, яким фактично відводилася першочергова роль.

7. На виборах до органів місцевого самоврядування $b$ найбільшій мірі обмежено активне виборче право порівняно з парламентськими та президентськими виборами b Україні. Анексія Російською Федерацією Кримського півострова та проведення Антитерористичної операції в окремих районах Донецької та Луганської області суттево вплинули на реалізацію виборчого права громадян України, які проживали або мали реєстрацію місця проживання на вказаних територіях [19]. Обмеженість у можливості реалізації виборчого права цією категорією виборців наочно продемонстрували позачергові президентські та парламентські вибори 2014 року, а ще більше місцеві вибори 2015 року. Неможливість проведення виборів на вказаних територіях було визначено Законом України № 1207-VII «Про забезпечення прав і свобод громадян та правовий режим на тимчасово окупованій території України» від 15 квітня 
2014 року [20] та постановою Верховної Ради України № 254-VIII «Про визнання окремих районів, міст, селищ і сіл Донецької та Луганської областей тимчасово окупованими територіями» від 17 березня 2015 року [21].

У ст. 8 Закону України «Про забезпечення прав і свобод громадян та правовий режим на тимчасово окупованій території України» передбачено, що громадянам України, які проживають на тимчасово окупованій території, створюються умови для вільного волевиявлення під час виборів Президента України, народних депутатів України та всеукраїнського референдуму на іншій території України. Громадяни України, які проживають на тимчасово окупованій території, мають право реалізувати своє право голосу на таких виборах або всеукраїнському референдумі в спосіб зміни місця голосування без зміни виборчої адреси згідно з ч. 3 ст. 7 Закону України «Про Державний реєстр виборців». На тимчасово окупованій території вибори депутатів Верховної Ради Автономної Республіки Крим, депутатів місцевих рад, сільських, селищних, міських голів, місцевий референдум не проводяться. Органи ведення Держреєстру виборців, утворені на території AРК та м. Севастополь, ведення Державного реєстру виборців не здійснюють. Порядок доступу до записів про виборців, виборча адреса яких відноситься до території, на яку поширюються повноваження цих органів ведення Держреєстру виборців, а також актуалізації цих записів установлюються Центральною виборчою комісією [20].

Осіб, які виїхали з тимчасово окупованих територій на підконтрольну Україні частину території, у законодавстві України було визначено «внутрішньо переміщеними особами». Особливість їх правового статусу закріплено в Законі України № 1706-VII «Про забезпечення прав і свобод внутрішньо переміщених осіб» від 20 жовтня 2014 року. Відповідно до ч. 1 ст. 1 та ст. 8 цього Закону, внутрішньо переміщеною особою є громадянин України, іноземець або особа без громадянства, яка перебуває на території України на законних підставах та має право на постійне проживання в Україні, яку змусили залишити або покинути своє місце проживання в результаті або для уникнення негативних наслідків збройного конфлікту, тимчасової окупації, повсюдних проявів насильства, порушень прав людини та надзвичайних ситуацій природного чи техногенного характеру. Внутрішньо переміщена особа реалізує своє право голосу на виборах Президента України, народних депутатів України, місцевих виборах та референдумах у спосіб зміни місця голосування без зміни виборчої адреси згідно з ч. 3 ст. 7 Закону України «Про Державний реєстр виборців» [22].

Практика проведення виборів до органів місцевого самоврядування протягом 2015-2019 років наочно засвідчила про обмеженість реалізації виборчого права внутрішньо переміщеними особами в Україні. Уперше обмеження щодо реалізації активного виборчого права внутрішньо переміщеними особами в Україні на виборах до органів місцевого самоврядування мали місце на чергових місцевих виборах, які відбулися 25 жовтня 2015 року. Вибори до органів місцевого самоврядування не проходили на території Автономної Республіки Крим та міста Севастополя, а також в окремих районах Донецької та Луганської областей. У зв'язку з цим вибори до місцевих рад на території Криму, а також вибори до Луганської й 
Донецької обласних рад та деяких місцевих рад указаних регіонів не проводилися. Тобто це означає, що вказані виборні органи на сьогодні так і залишаються несформованими.

Сутнісною рисою місцевих виборів 2015 року стало те, що близько 1,5 млн. громадян України, які були внутрішньо переміщеними особами, через установлення в новоприйнятому законі вимоги проживати в межах відповідного територіального виборчого округу, не змогли проголосувати на місцевих виборах у нових територіальних громадах. Обмеження активного виборчого права внутрішньо переміщених осіб на місцевих виборах $€$ необгрунтованим, оскільки в окремих регіонах частина зареєстрованих переселенців, за даними досліджень Інституту демографії та соціальних досліджень імені М.В. Птухи НАН України, сягає $5 \%$ населення, a їх загальна сукупність (з урахуванням тих, хто не ресструвався) - $10 \%$ [23, с. 77].

У ст. 3 Закону України «Про місцеві вибори» визначено, що право голосу на місцевих виборах мають громадяни України, які проживають на відповідній території в межах відповідного територіального виборчого округу [2]. Цікаво, що подібної вимоги вказаний закон не встановив для реалізації пасивного виборчого права, тобто висувати свої кандидатури для участі в місцевих виборах мали змогу всі громадяни України, зокрема й внутрішньо переміщені особи, а брати участь у голосуванні - лише громадяни, які проживають у межах відповідного територіального виборчого округу. Тож маємо доволі рідкий випадок, коли для реалізації активного виборчого права в межах одного виду виборчого цензу встановлено більш суворі вимоги, ніж для реалізації пасивного виборчого права.

На порушення виборчого права внутрішньо переміщених осіб у спосіб обмеження їх права голосу на місцевих виборах звернуто увагу й у Щорічній доповіді Уповноваженого Верховної Ради України з прав людини про стан додержання та захисту прав і свобод людини й громадянина в Україні 2018 року. У цій Доповіді зазначено, що впродовж 2015-2018 років залишається невирішеним питання забезпечення виборчих прав внутрішньо переміщених осіб, незважаючи на те що розв'язання цієї проблеми є важливою складовою рекомендацій зарубіжних партнерів України й міжнародних організацій. Держава та політичні суб'єкти наразі не сформували компроміс щодо законодавчого врегулювання виборчих прав внутрішньо переміщених осіб на місцевому рівні, i це негативно впливає на їх інтеграцію до адміністративної територіальної громади за місцем проживання [24].

У 2018 році громадянин М. А. Бабак подав до Конституційного Суду України скаргу (зареєстрована в КСУ 31 травня 2018 року під номером 18/ 2749 (18)) щодо відповідності Конституції України (конституційності) положень частин 1 та 3 ст. 3, ч. 3 ст. 30 Закону України «Про місцеві вибори», ч. 3 ст. 7 Закону України «Про Державний реєстр виборців», які унеможливлюють реалізацію внутрішньо переміщеними особами права голосу на місцевих виборах.

8. На Виборах до органів місцевого самоврядування спостерігається найменша явка вибориів порівняно з парламентськими та президентськими виборами $b$ 
Україні, яка Від одних місиеВих ВиборіВ до інших постійно знижується. На останніх чергових місцевих виборах 2015 року явка виборців склала лише 46,61\%, що на 2,2\% менше за явку виборців на попередніх місцевих , які відбулися в 2010 році. Для порівняння, у 2014 році явка виборців на позачергових виборах Президента України склала 60,29\%, а на позачергових виборах народних депутатів України - 52,42\% [15]. Парадокс найменшої уваги виборців до місцевих виборів в Україні полягає в тому, що переважна більшість проблем, з якими стикаються громадяни безпосередньо в житті (погана інфраструктура в населених пунктах, незадовільна робота комунальних підприємств, організацій та установ, неконтрольована забудова у великих містах тощо), лежить саме в площині повноважень органів місцевого самоврядування. Влучною щодо цього є думка Джорджа Джина Нейтана, що «погана влада обирається гарними громадянами, які не голосують». У практиці проведення виборів до органів місцевого самоврядування в Україні мало місце застосування мажоритарної виборчої системи відносної більшості з установленим нижнім порогом, а також вимогою, що вибори визнаються такими, що відбулися, якщо в них узяло участь більше половини від загальної кількості зареєстрованих виборців. Скажімо, при проведенні місцевих виборів у 1994 році та місцевих виборів, які відбулися в 1995 році на території АРК, обраним уважався кандидат у депутати, який одержав на виборах найбільшу порівняно 3 іншими кандидатами кількість голосів виборців, які взяли участь у голосуванні, але не менш як 10\% зареєстрованих виборців. Кандидат на посаду голови Ради вважався обраним при додержанні вимог, передбачених для кандидата в депутати, за умови, якщо за нього проголосувало не менш як 25\% зареєстрованих виборців. Вибори визнавалися такими, що відбулися, якщо в них узяло участь більше половини від загальної кількості зареестрованих виборців.

Висновки. Чергові вибори до органів місцевого самоврядування є чи не найбільш складним їх видом. При проведенні виборів до органів місцевого самоврядування в Україні мають місце вісім основних особливостей: 1) велика кількість осіб, які обираються на виборах до органів місцевого самоврядування; 2) грошова застава на виборах до органів місцевого самоврядування в Україні має обмежений характер та не застосовується стосовно селищних та міських голів, старост, а також депутатів селищних та сільських рад; 3) під час виборів до органів місцевого самоврядування застосовується три різні види виборчої системи; 4) проведення виборів до органів місцевого самоврядування здійснюеться за відповідними територіальними одномандатними та багатомандатними виборчими округами; 5) розгалужена система територіальних виборчих комісій, які мають свій особливий статус, порядок формування, склад та повноваження; 6) велика кількість виборчих бюлетенів під час голосування, що уповільнює роботу дільничних виборчих комісій під час видачі виборчих бюлетенів, здійснення безпосереднього волевиявлення виборців, підрахунок виборчих бюлетенів та встановлення остаточного результату виборів; 7) на виборах до органів місцевого самоврядування у найбільшій мірі обмежено активне виборче право порівняно з парламентськими та президентськими виборами 
в Україні; 8) на виборах до органів місцевого самоврядування спостерігається найменша явка виборців порівняно з парламентськими та президентськими виборами в Україні, яка від одних місцевих виборів до інших постійно знижується.

\section{Використані джерела:}

1. Конституція України: прийнята на п'ятій сесії Верховної Ради України 28 червня 1996 року. Відомості Верховної Ради України. 1996. № 30. Ст. 141.

2. Про місцеві вибори: закон України від 14 липня 2015 року № 595-VIII. Відомості Верховної Ради України. 2015. № 37-38. Ст. 366.

3. Кодекс адміністративного судочинства України від 06 липня 2005 року № 2747-IV. Офіційний Вісник України. 2005. № 32. Ст. 1918.

4. Про Центральну виборчу комісію: закон України від 30 червня 2004 року № 1932-IV. Відомості Верховної Ради України. 2004. № 36. Ст. 448.

5. Про Державний реєстр виборців: закон України від 22 лютого 2007 року № 698-V. Відомості Верховної Ради України. 2007. № 20. Ст. 282.

6. Батанов О. В. Політичні партії та територіальні громади як суб'єкти муніципального виборчого процесу. Вісник Центральної Виборчої комісії. 2005. № 2. С. 2.

7. Богашов О. А. Конституційно-правовий статус органів управління виборчим процесом в Україні: монографія. К., 2013. 272 с.

8. Козюбра М. Принцип верховенства права й реформа виборчої системи. Вибори та демократія. 2008. №4. С. 84-87.

9. Максакова Р. М. Вибори до органів місцевого самоврядування: проблеми теорії та практики. Автореферат дис. канд. юрид. наук. К., 2003. 15 с.

10. Марцеляк О. В. Виборче право: сучасне розуміння і сутність. Публічне право. 2011. № 2. С. 12-18.

11. Виборче право України: навч. посіб. / за ред. В. Ф. Погорілка, М. І. Ставнійчук. Київ: Парламентське вид-во, 2003. 383 с.

12. Смокович М. I. Правове регулювання розгляду виборчих спорів: теоретичний і практичний аспекти: монографія. Київ: Юрінком Інтер, 2014. 576 с.

13. Федоренко В. Л. Конституційне право України: підручник. Київ: Видавництво Ліра-К, 2016. 616 с.

14. Про місцеве самоврядування в Україні: закон України від 21 травня 1997 року № 280/97-ВР. Відомості Верховної Ради України. 1997. № 24. Ст.170.

15. Систематизовано автором на основі даних Центральної виборчої комісії. Центральна виборча комісія. URL: https:/ /www.cvk.gov.ua.

16. Про вибори депутатів місцевих рад та сільських, селищних, міських голів: закон України від 14 січня 1998 року № 14/98-ВР. Відомості Верховної Ради України. 1998. № 3-4. С. 15.

17. Фесенко В. Вибори 2006: практичне тестування пропорційної виборчої системи. Вибори та демократія. 2006. № 4. С. 4-13.

18. Ukraine, Local Elections, 25 October and 15 November 2015: Final Report / OSCE/ODIHR Election Observation Mission. Warsaw, 2016. 58 p.

19. Нестерович В. Ф. Верховенство права та забезпечення прав людини на тимчасово окупованих територіях України. Наукові записки НаУКМА. 2017. Т. 200. Юридичні науки. С. 85-92.

20. Про забезпечення прав і свобод громадян та правовий режим на тимчасово окупованій території України: закон України від 15 квітня 2014 року № 1207-VII. Відомості Верховної Ради України. 2014. № 26. Ст. 892. 
21. Про визнання окремих районів, міст, селищ і сіл Донецької та Луганської областей тимчасово окупованими територіями: постанова Верховної Ради України від 17 березня 2015 року № 254-VIII. Відомості Верховної Ради Украӥни. 2015. № 17. C.128.

22. Про забезпечення прав і свобод внутрішньо переміщених осіб: закон України від 20 жовтня 2014 року № 1706-VII. Відомості Верховної Ради України. 2015. № 1. С. 1.

23. Щорічна доповідь Уповноваженого Верховної Ради України $з$ прав людини про стан додержання та захисту прав і свобод людини і громадянина в Україні. Київ, 2015. 552 с.

24. Щорічна доповідь Уповноваженого Верховної Ради України 3 прав людини про стан додержання та захисту прав і свобод людини і громадянина в Україні. Київ, 2018. 134 с.

\section{References}

1. Konstytutsiya Ukrayiny: pryynyata na p"yatiy sesiyi Verkhovnoyi Rady Ukrayiny 28 chervnya 1996 roku [Constitution of Ukraine: adopted at the fifth session of the Verkhovna Rada of Ukraine on June 28, 1996]. Vidomosti Verkhovnoyi Rady Ukrayiny. 1996. № 30. St. 141. [in Ukrainian]

2. Pro mistsevi vybory: Zakon Ukrayiny vid 14 lypnya 2015 roku № 595-VIII [Law of Ukraine «On local elections» from July 14, 2015 № 595-VIII]. Vidomosti Verkhovnoyi Rady Ukrayiny. 2015. № 37-38. St. 366. [in Ukrainian]

3. Kodeks administratyvnoho sudochynstva Ukrayiny vid 6 lypnya 2005 roku № 2747-IV [The Code of Administrative Legal Proceedings of Ukraine from July 6, 2005 No. 2747-IV]. Ofitsiynyy visnyk Ukrayiny. 2005. № 32. St. 1918. [in Ukrainian]

4. Pro Tsentral'nu vyborchu komisiyu: Zakon Ukrayiny vid 30 chervnya 2004 roku № 1932-IV [Law of Ukraine «On the Central Election Commission» from June 30, 2004 No. 1932-IV]. Vidomosti Verkhovnoyi Rady Ukrayiny. 2004. № 36. St. 448. [in Ukrainian]

5. Pro Derzhavnyy reyestr vybortsiv: Zakon Ukrayiny vid 22 lyutoho 2007 roku № 698-V [Law of Ukraine «On the State Register of Voters» from February 22, 2007 No. 698-V]. Vidomosti Verkhovnoyi Rady Ukrayiny. 2007. № 20. St. 282. [in Ukrainian]

6. Batanov O.V. (2005) Politychni partiyi ta terytorial'ni hromady yak sub"yekty munitsypal'noho vyborchoho protsesu [Political parties and territorial communities as subjects of the municipal electoral process]. Visnyk Tsentral'noyi vyborchoyi komisiyi..vol. 2, s. 2. [in Ukrainian]

7. Bohashov O.A. (2013) Konstytutsiyno-pravovyy status orhaniv upravlinnya vyborchym protsesom $v$ Ukrayini: monohrafiya [The constitutional and legal status of electoral process management bodies in Ukraine: a monograph]. Kiev. 272 s. [in Ukrainian]

8. Kozyubra M. (2008) Pryntsyp verkhovenstva prava i reforma vyborchoyi systemy [Principle of rule of law and reform of the electoral system. Elections and democracy]. Vybory ta demokratiya. vol. 4, s. 84-87. [in Ukrainian]

9. Maksakova R. M. (2003) Vybory do orhaniv mistsevoho samovryaduvannya: problemy teoriyi ta praktyky [Elections to local self-government bodies: problems of theory and practice]. Avtoreferat dys. kand. yuryd. nauk. Kiev. 15 p. [in Ukrainian]

10. Martselyak O.V. Vyborche pravo: suchasne rozuminnya $i$ sutnist' [Election law: modern understanding and essence]. Publichne pravo. 2011. vol. 2. s. 12-18. [in Ukrainian]

11. Vyborche pravo Ukrayiny: Navch. posib. [Election Law of Ukraine: Teach. manual] (2003) / Za red. V.F. Pohorilka, M.I. Stavniychuk. Kiev: Parlament s'ke vyd-vo. 383 p. [in Ukrainian] 
12. Smokovych M. I. (2014) Pravove rehulyuvannya rozhlyadu vyborchykh sporiv: teoretychnyy i praktychnyy aspekty: monohrafiya [Legal regulation of electoral disputes: theoretical and practical aspects: monograph]. Kiev: Yurinkom Inter. 576 p. [in Ukrainian]

13. Fedorenko V.L. (2016) Konstytutsiyne pravo Ukrayiny: Pidruchnyk [Constitutional Law of Ukraine: Textbook]. Kiev: Vydavnytstvo Lira-K. 616 s. [in Ukrainian]

14. Pro mistseve samovryaduvannya v Ukrayini: Zakon Ukrayiny vid 21 travnya 1997 roku № 280/97-VR [Law of Ukraine «On Local Self-Government in Ukraine» from May 21, 1997 No. 280/97-BP]. Vidomosti Verkhovnoyi Rady Ukrayiny. 1997. № 24. St.170. [in Ukrainian]

15. Systematyzovano avtorom na osnovi danykh Tsentral'noyi vyborchoyi komisiyi. Tsentral'na vyborcha komisiya [Systematized by the author based on data from the Central Election Commission]. URL: https:/ / www.cvk.gov.ua. [in Ukrainian]

16. Pro vybory deputativ mistsevykh rad ta sil's'kykh, selyshchnykh, mis'kykh holiv: Zakon Ukrayiny vid 14 sichnya 1998 roku № 14/98-VR [Law of Ukraine «On elections of deputies of local councils and village, settlement, city mayors» from 14 January 1998 No. 14/98-VR]. Vidomosti Verkhovnoyi Rady Ukrayiny. 1998. № 3-4. St.15. [in Ukrainian]

17. Fesenko V. (2006) Vybory 2006: Praktychne testuvannya proportsiynoyi vyborchoyi systemy [Elections 2006: Practical testing of the proportional electoral system]. Vybory ta demokratiya. vol. 4, s. 4-13. [in Ukrainian]

18. Ukraine, Local Elections, 25 October and 15 November 2015: Final Report / OSCE/ODIHR Election Observation Mission. Warsaw, 2016. $58 \mathrm{~s}$.

19. Nesterovych V.F. Verkhovenstvo prava ta zabezpechennya prav lyudyny na tymchasovo okupovanykh terytoriyakh Ukrayiny [The rule of law and human rights in the temporarily occupied territories of Ukraine]. Naukovi zapysky NaUKMA. 2017. vol. 200. Yurydychni nauky. s. 85-92. [in Ukrainian]

20. Pro zabezpechennya prav i svobod hromadyan ta pravovyy rezhym na tymchasovo okupovaniy terytoriyi Ukrayiny: Zakon Ukrayiny vid 15 kvitnya 2014 roku № 1207-VII [Law of Ukraine «On ensuring the rights and freedoms of citizens and legal regime in the temporarily occupied territory of Ukraine» from April 15, 2014 № 1207 VII]. Vidomosti Verkhovnoyi Rady Ukrayiny. 2014. № 26. St. 892. [in Ukrainian]

21. Pro vyznannya okremykh rayoniv, mist, selyshch i sil Donets'koyi ta Luhans'koyi oblastey tymchasovo okupovanymy terytoriyamy: Postanova Verkhovnoyi Rady Ukrayiny vid 17 bereznya 2015 roku № 254-VIII [On recognition of individual districts, cities, villages and villages of Donetsk and Lugansk regions of the temporarily occupied territories: Resolution of the Verkhovna Rada of Ukraine from March 17, 2015 No. 254-VIII]. Vidomosti Verkhovnoyi Rady Ukrayiny. 2015. № 17. St.128. [in Ukrainian]

22. Pro zabezpechennya prav i svobod vnutrishn'o peremishchenykh osib: Zakon Ukrayiny vid 20 zhovtnya 2014 roku № 1706-VII [Law of Ukraine «On ensuring the rights and freedoms of internally displaced persons» from October 20, 2014 No. 1706VII]. Vidomosti Verkhovnoyi Rady Ukrayiny. 2015. № 1. St. 1. [in Ukrainian]

23. Shchorichna dopovid' Upovnovazhenoho Verkhovnoyi Rady Ukrayiny z prav lyudyny pro stan doderzhannya ta zakhystu prav i svobod lyudyny i hromadyanyna v Ukrayini [Annual report of the Ukrainian Parliament Commissioner for Human Rights on the state of observance and protection of human rights and freedoms in Ukraine]. K., 2015. 552 s. [in Ukrainian]

24. Shchorichna dopovid' Upovnovazhenoho Verkhovnoyi Rady Ukrayiny z prav lyudyny pro stan doderzhannya ta zakhystu prav i svobod lyudyny i 
hromadyanyna v Ukrayini [Annual report of the Ukrainian Parliament Commissioner for Human Rights on the state of observance and protection of human rights and freedoms in Ukraine]. K., 2018. 134 s. [in Ukrainian]

Стаття надійшла до редколегї 02.05.2019

Нестерович В. $\Phi$., доктор юридических наук, доцент, заведующий кафедрой государственно-правовых дисциплин Луганского государственного университета внутренних дел имени Э. А. Дидоренко (г. Северодонецк, Украина)

\section{ОСОБЕННОСТИ ПРОВЕДЕНИЯ ВЫБОРОВ В ОРГАНЫ МЕСТНОГО САМОУПРАВЛЕНИЯ В УКРАИНЕ}

В статье раскрыты особенности проведения выборов в органы местного самоуправления в Украине. Указывается, что выборы в органы местного самоуправления являются наиболее приближенным видом выборов к гражданам. Очередные выборы в органы местного самоуправления являются едва ли не самым сложным видом выборов. При проведении выборов в органы местного самоуправления в Украине имеют место восемь основных особенностей, которые заметно отличают этот вид выборов по сравнению с парламентскими и президентскими выборами в Украине.

Ключевые слова: выборы, избирательное право, избирательный процесс, избирательная система, органы местного самоуправления, Украина.

Nesterovych V., doctor of law, associate professor, head of the department of state-legal disciplines, Lugansk state university of internal affairs named after E. O. Didorenko (Sievierodonetsk, Ukraine)

\section{FEATURES OF ELECTION TO LOCAL SELF-GOVERNMENT BODIES IN UKRAINE}

The article describes the peculiarities of conducting elections to local self-government bodies in Ukraine. It is pointed out that elections to local self-government bodies are the most approximate type of elections for citizens. Regular elections to local self-government bodies are perhaps the most difficult form of election. In conducting elections to local selfgovernment bodies in Ukraine, there are eight main features that distinguish this type of election significantly in comparison with parliamentary and presidential elections in Ukraine.

The author concludes that during the elections to the local self-government bodies in Ukraine there are the following eight main features: 1) a large number of persons elected to elections to local self-government bodies; 2) the monetary deposit in elections to local selfgovernment bodies in Ukraine is of limited scope and does not apply to village and city mayors, elders, as well as deputies of village and village councils; 3 ) during the elections to 
local self-government bodies three different types of electoral system are used; 4) elections to local self-government bodies are carried out in the respective territorial single-mandate and multi-mandate constituencies; 5) ramified system of territorial election commissions that have their own special status, the order of formation, composition and powers; 6) a large number of ballot papers during the voting, which slows down the work of the polling station election commissions during the issuance of ballot papers, the direct expression of the will of the voters, the counting of ballot papers and the establishment of the final election result; 7) in the elections to local self-government bodies, the active participation of electoral rights is limited to the greatest extent compared to parliamentary and presidential elections in Ukraine; 8) in the elections to local self-government bodies, the smallest turnout of voters is observed compared to parliamentary and presidential elections in Ukraine, which is steadily decreasing from one local election to another.

Key words: elections, electoral law, electoral process, electoral system, local selfgovernment bodies, Ukraine.

\section{DOI}

УДК 349.2 (477)

Л. В. Перевалова,

кандидат філософських наук, доцент, завідувач кафедри права Національного технічного університету «Харківський політехнічни інститут» (м. Харків, Україна) e-mail: perevalovaluda@ukr.net, iD https:// orcid.org/0000-0001-5182-2838

I. В. Лисенко, кандидат юридичних наук, доцент, доцент кафедри права Національного технічного університету «Харківський політехнічний інститут» (м. Харків, Україна) e-mail: irina8119@ukr.net iD https://orcid.org/0000-0003-3392-6056

А. М. Лисенко, кандидат юридичних наук, доцент, доцент кафедри оперативно - розшукової діяльності Харківського національного університету внутрішніх справ (м. Харків, Україна)

e-mail: lan11.07.1979@gmail.com, (iD https:/ / orcid.org/0000-0003-0780-2148

\section{ПРОБЛЕМИ ПРАЦЕВЛАШТУВАННЯ МОЛОДІ НА СУЧАСНОМУ ЕТАПІ РОЗВИТКУ УКРАЇНСЬКОГО СУСПІЛЬСТВА}

Стаття присвячена проблемам молоді на ринку праці в Україні, серед яких: безробіття, низький рівень життя, небажання роботодавців оформлювати легальні трудові відносини, зростання міграційних процесів, пов'язаних із (C) Перевалова Л. В., Лисенко І. В., Лисенко А. М., 2019 